\title{
COMPARATIVE ADMINISTRATIVE LAW: OUTLINING A FIELD OF STUDY
}

\author{
Susan Rose-Ackerman* \\ Peter L. Lindseth**
}

Comparative administrative law is emerging as a distinct field of inquiry after a period of neglect. To demonstrate this claim, the authors summarize their edited volume on the topic - a collection that aims to stimulate research across legal systems and scholarly disciplines. After a set of historical reflections, the authors consider key topics at the intersection of administrative and constitutional law, including the contested issue of administrative independence. Two further sections bighlight tensions between expertise and accountability, drawing insights from economics and political science. The essay then considers the changing boundaries of the administrative state - both the public-private distinction and the links between domestic and transnational regulatory bodies, such as the European Union. The essay concludes with reflections on a core concern of administrative law: the way individuals and organizations across different systems test and challenge the legitimacy of public authority.

Le droit administratif comparé est en train de se manifester comme domaine d'étude distinct suite à une période pendant laquelle il a été négligé. Pour démontrer cette affirmation, les auteurs présentent un sommaire du volume à ce sujet dont ils dirigent la publication - une collection qui vise à stimuler la recherche au sein de divers systèmes juridiques et diverses disciplines d'érudition. Après une série de réflexions historiques, les auteurs traitent de questions-clés qui relèvent en même temps du droit administratif et du droit constitutionnel, y compris la question controversée de l'indépendance administrative. Deux autres sections mettent en lumière des tensions entre l'expertise et l'obligation de rendre compte, puisant dans les sciences économique et politique. L'article traite ensuite des limites changeantes de l'état administratif - d'une part, quant à la distinction public-privé et d'autre part, quant aux liens entre les organismes de réglementation domestiques et transnationaux, telle que l'Union européenne. L'article se termine avec des réflexions sur une préoccupation de fond $d u$ droit administratif : la facon dont les individus et les organisations dans des systèmes différents mettent à l'épreuve et contestent la légitimité de l'autorité publique.

\section{INTRODUCTION}

The American political scientist Frank Goodnow published his classic study on comparative administrative law in 1903. ${ }^{1}$ Unfortunately, this auspicious beginning did

* Henry R. Luce Professor of Jurisprudence (Law and Political Science) with joint appointments between Yale Law School and the Yale Department of Political Science.

** Olimpiad S. Ioffe Professor of International and Comparative Law, University of Connecticut Law School 
not precipitate sustained scholarly interest in the field over the coming century. As a focus of comparative study, administrative law has languished relative to its domestic counterpart, which flourished in the twentieth century with rise of the modern administrative state. The relative neglect of comparative administrative law is now changing, and we aim to contribute to its renaissance with our edited book, Comparative Administrative Law. ${ }^{2}$ Our goal in that volume and in this essay is to survey the field in order to document renewed scholarly attention to this rich and compelling field of study. Our hope is that these collected essays will help to generate interest in the field and to suggest promising arenas for future research.

Administrative law cannot avoid confrontations with politics. Perhaps even more than constitutional law, it frames the interaction between law and politics; it provides the conceptual vocabulary for their transformation over time in response to social change. In the western tradition administrative law initially reflected the growing distinction between state and society, and it mediated between those seemingly distinct realms. Over the course of the twentieth century, it served a similar mediating function as the regulatory state emerged. It flourished in the space opened up by the instability of the classic triad of legislative, executive, and judicial power. It came to define the often murky terrain between the institutions of government (in which those powers were purportedly "constituted") and the diffuse and fragmented realm of regulation in all of its many manifestations. Today, throughout the world, at the borders between the private and public sectors and between nation states and transnational bodies, administrative law continues to be a realm of legal contestation and redefinition. It is not just about fair and transparent procedures; honest, hardworking officials; and the protection of individual rights - although these are all important. It also concerns the democratic legitimacy of government policymaking. A fair and open policymaking process helps democratic citizens hold modern government to account in the face of demands for delegation and regulation, both within and beyond the state.

In opting for a broad conception of the field, our goal is to break down boundaries between scholars, not only those from different national or legal traditions, but also those from different disciplinary or doctrinal perspectives. One of us has a background in economics and political science (Rose-Ackerman); the other in the legal and social history of the state (Lindseth). We meet on the common ground of comparative administrative law and regulatory practice. In our edited volume we have drawn from a wide range of legal scholarship, ranging from constitutional law, state and local government law, regulated industries, European integration, transnational litigation, public international law, as well as administrative law more traditionally conceived.

\footnotetext{
Frank J. Goodnow, Comparative Administrative Law: An Analysis of the Administrative Systems National and Local, of the United States, England, France, and Germany (New York and London: Knickerbocker, 1903).

2 This essay is adapted from our introduction to Susan Rose-Ackerman \& Peter L. Lindseth, eds, Comparative Administrative Law (Cheltenham UK: Edward Elgar, 2010). That volume resulted from a conference held at Yale Law School in May 2009 with the support of Yale Law School's Oscar M. Ruebhausen Fund.
} 


\section{ADMINISTRATIVE LAW AS HISTORICAL INSTITUTION}

Because administrative law is intimately bound up with the development of the modern state, the study of administrative law can usefully begin with historical reflections on its interactions with social and political change over the last two centuries. As a phenomenon in western history, the emergence of administrative law has been intimately tied to the increasing "specificity and subjectivity" of public administrative power since the end of the eighteenth century. In Western Europe, and by extension in North America, "administrative power" and "administrative law" emerged in tandem over the course of the nineteenth century, although at clearly different paces. ${ }^{4}$ Moreover, owing to quite different institutional and conceptual starting points, the results of this process often differed as well. The substantive and procedural distinctions are now well known: Rechtsstaat/Etat de droit enforced by specialized administrative judges in the continental tradition, on the one hand; and Rule of Law enforced by the ordinary judiciary in the Anglo-American tradition, on the other. ${ }^{5}$

Despite these differences, the conjunction between a specifically public administrative power within the state and a body of law to constrain that power holds true more broadly, as the experience of other regions of the world suggests. In East Asia, for example, although the term "administrative law" was unknown prior to contact with the West, the prevailing traditional system of government - with its commands from higher to lower level officials; its proliferation of regulatory mandates; its definition of competences; and its ambition for a "professional, disciplined, meritocratic, and rule-bound" body of public servants - suggests that East Asia may well have been something of a pioneer in the development of constraints on specifically administrative action. ${ }^{6}$ Traditional East Asian law lacked, however, a realm of "private" right distinct from the realm of public governance. It is also certainly true that, up to the end of the eighteenth century, old regime monarchies in Europe ruled through a corporatist system of privileges and jurisdictions grounded in conceptions of right (notably "property") that we would today clearly see as private. Nevertheless, it was precisely the progressive extrication of "public" authority from this corporatist old regime by the end of the eighteenth century, as well as the development of a distinct corps of public servants to pursue and defend these new public prerogatives over the course of the nineteenth, that marked the emergence of administrative modernity in the Western world. However, with its eventual contact with the West, East Asian law, through a process of copying

3 Bernardo Sordi, "Révolution, Rechtsstaat, and the Rule of Law: Historical Reflections on the Emergence of Administrative Law in Europe" in Rose-Ackerman \& Lindseth, supra note 2 at ch. 1.

4 See e.g. Jerry Mashaw, "Explaining Administrative Law: Reflections on Federal Administrative Law in Nineteenth Century America" in Rose-Ackerman \& Lindseth, supra note 2 at ch. 2.

5 See e.g. Peter L. Lindseth, “'Always Embedded” Administration: The Historical Evolution of Administrative Justice as an Aspect of Modern Governance" in Christian Joerges, Bo Stråth \& Peter Wagner, eds, The Economy as a Polity: The Political Constitution of Contemporary Capitalism, (London: UCL Press, 2005).

6 John Ohnesorge, "Administrative Law in East Asia: a Comparative-Historical Analysis" in RoseAckerman \& Lindseth, supra note 2 at ch. 5. 
(what organizational theorists call isomorphism), began to mimic these basic features of a modern administrative law regime.

Depending on the polity, this emergent corps of public servants in Europe, the United States and elsewhere did not necessarily conform to the Weberian ideal type of bureaucracy. ${ }^{8}$ Over the course of the nineteenth century, what united the more bureaucratic forms of administrative power on the European continent with their relatively less bureaucratized counterparts in Britain and North American was the increasing importance of positive law - legislation - in framing the limits of public authority. And as legislatures increasingly democratized, ' the pressure on the state to intervene in society also increased, whether via a Weberian bureaucracy or other mechanisms. This went along with demands that its agencies and officials operate in a legally constrained, transparent, and accountable fashion.

Moving from the nineteenth to the twentieth century, changes in the underlying functions of the state in the twentieth century influenced the development of administrative law. ${ }^{10}$ The rise of industry with monopoly power and the privatization of formerly state - controlled sectors produced a demand for the control of markets to which all developed states responded, albeit in different ways. Moreover, administrative law has sometimes checked populist or democratic demands by giving organized and powerful economic interest groups a way to challenge policy. There is an ongoing tension in the political and historical analysis of administrative law. Public law provisions that are justified as a check on overarching state power can also be a means of entrenching existing private interests. Legal constraints may under some conditions limit the ability of democratic governments to constrain concentrated, monopolistic economic interests.

\section{CONSTITUTIONAL STRUCTURE AND ADMINISTRATIVE LAW}

Turning to more present concerns, administrative law has been shaped by differences in constitutional structure across various states - for example, presidential or parliamentary; democratic or authoritarian; federal or unitary; tripartite or more multi-faceted. Constitutional texts and administrative law interact to shape the rights and duties of professional administrators, elected politicians, and judges. Even though public administration and the bureaucracy receive little detailed treatment in the texts of most constitutions, they form the backbone of state functioning. ${ }^{11}$

One way to approach the links between constitutional structure and administrative law is through the lens of political economy, and more particularly through the work of positive political theory [PPT]. Unlike explicitly normative work

\section{Ibid.}

$8 \quad$ Nicholas Parrillo, "Testing Weber: Compensation for Public Services, Bureaucratization, and the Development of Positive Law in the United States" in Rose-Ackerman \& Lindseth, supra note 2 at ch. 3 .

9 See e.g. Charles Tilly, Contention and Democracy in Europe, 1650-2000 (New York: Cambridge University Press, 2003) at 213-217 for "A Rough Map of European Democratization" over the nineteenth and twentieth centuries.

10 Marco d'Alberti, "Administrative Law and the Public Regulation of Markets in a Global Age" in Rose-Ackerman \& Lindseth, supra note 2 at ch. 4.

11 Tom Ginsburg, "Written Constitutions and the Administrative State: On the Constitutional Character of Administrative Law" in Rose-Ackerman \& Lindseth, supra note 2 at ch. 7. 
in constitutional law and political theory, PPT attempts to model state behaviour in terms of the self-interest of the actors involved. ${ }^{12}$

US-focused PPT would predict that parliamentary systems would provide for lower levels of judicial oversight of the administration than presidential systems. PPT explains judicial review in the US as a result of the legislature's desire to check the executive and its inability to do this effectively on its own. Thus, the legislature is the dominant actor that can assign tasks to the courts. In a parliamentary system the same political coalition controls both branches, and so legislators from the majority coalition would not want the courts to intervene to oversee executive action. In contrast to these expectations, comparative analysis finds that courts in the UK, France and Germany are, in fact, quite active in reviewing administrative actions. ${ }^{13}$ Either the theory of legislative dominance has limited force, or other factors prevent the government from constraining the courts. The courts themselves seem to be independent actors at least insofar as they assert jurisdiction and oversee the executive. If judges believe that executive discretion needs to be controlled and if the legislature is doing little, they may step in, grant standing to public interest plaintiffs and limit executive power. ${ }^{14}$

Federalism and central/local relations are a key aspect of constitutionaladministrative structure in both the EU and the US. Strong notions of Member State sovereignty in the EU as well as dual sovereignty in the US make it difficult to carry out a coherent policy in either polity. It is all very well to speak of EU-style subsidiarity as a principle for dividing authority, but if the subordinate governments differ in their capacities and organization, and if they must cooperate to achieve policy goals, then simply allocating tasks down the governmental chain will not work. Both central control and cross-government cooperation are needed as well as local knowledge and implementation. ${ }^{15}$

This raises an important general issue. If the structures of administrative and constitutional law hamper competent policy implementation, how ought one to reconcile established legal traditions with pragmatic efforts to better balance expertise and accountability with the protection of individual rights? One of us has argued elsewhere that this challenge inevitably entails a complex mix of "resistance and reconciliation" - normative resistance animated by those constitutional traditions, on the one hand, but also a necessary degree of reconciliation to the demands for efficient problem solving, on the other. ${ }^{16}$ The result, however, will almost certainly be suboptimal if judged by the criteria of either perspective alone.

12 For a collection of articles that apply the approach to administrative law see Susan Rose-Ackerman, ed, Economics of Administrative Law (Cheltenham UK: Edward Elgar, 2007).

13 M. Elizabeth Magill \& Daniel R. Ortiz, "Comparative Positive Political Theory" in Rose-Ackerman $\&$ Lindseth, supra note 2 at ch. 9.

14 Tom Zwart, "Overseeing the Executive: Is the Legislature Reclaiming Lost Territory from the Courts?" in Rose-Ackerman \& Lindseth, supra note 2 at ch. 10.

15 Fernanda G. Nicola, “'Creatures of the State’: Regulatory Federalism, Local Immunities, and EU Waste Regulation in Comparative Perspective" in Rose-Ackerman \& Lindseth, supra note 2 at ch. 11.

16 Peter L. Lindseth, Power and Legitimacy: Reconciling Europe and the Nation-State (Oxford: Oxford University Press, 2010). 


\section{ADMINISTRATIVE INDEPENDENCE AND ADMINISTRATIVE LAW}

Administrative independence is often defended as a way to assure that decisions are made by neutral professionals with the time and technical knowledge to make competent, apolitical choices. The heart of the controversy over independence which we suggest is ubiquitous - usually stems from a disconnect between much modern administration and traditional democratic accountability that flows from voters through elected politicians to the bureaucracy. Attempts to legitimate entities, such as the many so-called "independent agencies," in traditional democratic terms often stresses the importance of processes that go beyond expertise to incorporate public opinion and social and economic interests. The ideal is an expert agency that is independent of partisan politics but sensitive to the concerns of ordinary citizens and civil society groups. The risk is capture by narrow interests.

To take one example, the independence of agencies is much contested in common law parliamentary jurisdictions where the tension between notions of unitary government policymaking and agency independence are also often in serious tension. Canada, for example, has a particularly vexed history because of a lack of clarity about the place of such agencies in the structure of government. The UK, Australia and New Zealand have, in contrast, given independent agencies a clearer and more well-articulated position in their governmental structures. ${ }^{17}$ In the US independent regulatory commissions attempt to address democratic concerns by building in partisan balance. Instead of requiring technocratic expertise or professional credentials, most agency statutes set up a multi-member governing board and require that no more than a bare majority can be from a single political party. For example, in a five-member board, no more than three can have the same party affiliation. As with the US judiciary, the appointment process is highly political. But with fixed, staggered terms and party balance, agencies can, in principle, respond to changing conditions as their membership changes gradually over time.

This feature of US commissions has not been copied in the EU. The European Union has substituted "technocratic for democratic legitimacy." ${ }^{18}$ Agencies have proliferated at the EU level in recent years, but rather than seeking partisan balance based on political party affiliation, Member States are represented on agency boards. ${ }^{19}$ This practice is a political compromise, but, in practice, it leads to the dominance of technical experts who are appointed by Member States and interact with their respective specialized ministries. Outside of North America and Europe, the creation and operation of agencies have been influenced by both American and European legal models but often have distinctive features. For example, in Brazil although the independent agency model was borrowed from the United States, Brazilian agencies

17 Lorne Sossin, "The Puzzle of Administrative Independence and Parliamentary Democracy in the Common Law World: A Canadian Perspective" in Rose-Ackerman \& Lindseth, supra note 2 at ch. 13.

18 Martin Shapiro, “A Comparison of U. S. and European Independent Agencies" in Rose-Ackerman \& Lindseth, supra note 2 at ch. 18. See also Giandominico Majone, "Two Logics of Delegation: Agency and Fiduciary Relations in EU Governance” (2001) 2 European Union Politics 103.

19 Johannes Saurer, "Supranational Governance and Networked Accountability: Member State Oversight of EU Agencies” in Rose-Ackerman \& Lindseth, supra note 2 at ch. 36. 
are clearly subordinate to the executive..$^{20}$ Hence, they have struggled to provide credible commitments to investors both domestic and foreign and to ordinary citizens and civil society groups. In Taiwan an independent regulatory agency for telecommunications ran up against a Supreme Court that struck down an appointments process that gave too large a role to the legislature. ${ }^{21}$

\section{PROCESS AND POLICY}

Public agencies promulgate regulations for many different purposes. They seek to correct market failures, protect rights, and distribute the benefits of state actions to particular groups - ranging from the poor or disadvantaged minorities to politically powerful industries such as agriculture or oil and gas. Executive policymaking in democracies raises issues of public legitimacy, and this is a central focus of administrative law in the United States where the notice and comment provisions of the Administrative Procedure Act $[A P A]$ guide the process. ${ }^{22}$ These provisions require agencies to provide notice, hold hearings, and give reasons when they issue a rule. The final rule can then be subject to judicial review, which reaches beyond compliance with the procedural demands of the $A P A$ both to the rational underpinnings of the rule and to its consistency with the implementing statute.

Discussions of "good" policy by social scientists, risk analysts, and other specialists sometimes clash with the focus of American administrative law on transparency and participation. This tension between technical competence and mechanisms to promote legitimacy may be less evident in other legal systems where the law does little to constrain policymaking processes compared with the adjudication of individual administrative acts. ${ }^{23}$ Judicial review, except where human rights or other constitutional prescriptions are at stake, does not usually take on the merits of broad policy choices.

For example, one can compare the way politics and policymaking interact in the contrasting experience of the US and the EU. In the United States an executive order mandates White House review of major regulations produced in the core executive branch. ${ }^{24}$ Such oversight extends beyond the implications of a program for the public

20 Mariana Mota Prado, "Presidential Dominance from a Comparative Perspective: the Relationship between the Executive Branch and Regulatory Agencies in Brazil," in Rose-Ackerman \& Lindseth, supra note 2 at ch.14.

21 Jiunn-rong Yeh, "Experimenting with Independent Commissions in a New Democracy with a Civil Administrative Law Tradition: The Case of Taiwan" in Rose-Ackerman \& Lindseth, supra note 2 at ch. 15. Other agencies police the accountability of the government itself. The case for independence is particularly strong for such agencies, but so is the need for oversight to prevent either their capture by regime opponents or their lapse into inaction. Given this risk, oversight agencies should be independent of the state but should also be subject to the scrutiny of ordinary citizens and civil society groups. John Ackerman, "Understanding Independent Accountability Agencies" in RoseAckerman \& Lindseth, supra note 2 at ch. 16.

22 U.S. Administrative Procedure Act, 5 U.S.C. $\$ \$ 553$ - 706.

23 Susan Rose-Ackerman, Controlling Environmental Policy: The Limits of Public Law in Germany and the United States (New Haven CT: Yale University Press, 1995); Susan Rose-Ackerman, From Elections to Democracy: Building Accountable Government in Hungary and Poland (Cambridge UK: Cambridge University Press, 2005).

24 The current executive order 12866 is available online: Office of Regulation and Regulatory Affairs, OMB < http://www.reginfo.gov/public/jsp/Utilities/EO_Redirect.jsp > President Obama issued a 
budget and measures the costs and benefits for society at large. The cost-benefit approach has, moreover, been particularly influential in the United States, but, a similar technique, called Impact Assessment [IA], is becoming increasingly common in Europe. ${ }^{25}$ There is a lively debate in Europe both over substantive review of policy based on economic principles and over the expansion of public participation and transparency requirements to cover rulemaking. However, this debate has had relatively little impact on administrative law, which has been largely silent concerning the policymaking process as opposed to decisions in individual cases.

Those urging greater reliance on economic criteria need to recognize that these approaches can themselves be tools to obtain political advantage. Thus, in the United States, White House review of regulations under cost-benefit criteria can help the president control the content of major regulations produced by executive branch agencies. ${ }^{26} \mathrm{~A}$ tool, which appears neutral on its face, can be manipulated for political ends. This is possible because any cost-benefit analysis involves many judgment calls. Seldom will there be a single "right" answer that anyone trained in the technique will accept. ${ }^{27}$ Thus, in a democratic polity cost-benefit analysis and similar technocratic tools, although useful in focusing policy debates, cannot be the sole criteria for choice.

However one views the debate over process as a matter of administrative law, it is a key area of contestation in terms of regulatory policy. The traditional tension in administrative law between technical expertise and accountability plays out somewhat differently in the US, the EU, and the UK. Courts can act as a counterweight to the prevailing ethos - upholding expertise in the US, and treating claims of expertise with caution in the EU. The UK courts, however, apparently view both public participation and expertise with caution, and they legitimate administrative action based on a Weberian understanding of a hierarchical, professional, politically neutral civil service. $^{28}$

Many participants in the debate over policy analysis privilege a particular type of expertise derived from science and economics. Others urge more transparent, participatory decision-making processes. The two approaches are compatible so long as state officials recognize that they may not have all the necessary expertise. Participation and transparency can serve not just as rights but also as means to the end of better policy outcomes. Greater public involvement may not only produce more effective policy but also increase the acceptability of the regulatory process both in representative democracies and in entities, such as the European Union, that also seek public legitimacy. As a practical matter, however, regulatory agencies may not

supplementary executive order 13563 on January 18, 2011. Online: Office of Information and Regulatory Affairs <http://www.reginfo.gov/jsp/utilities/EO_13563.pdf >.

25 Jonathan Wiener \& Alberto Alemanno, "Comparing Regulatory Oversight Bodies across the Atlantic: The Office of Information and Regulatory Affairs in the US and the Impact Assessment Board in the EU" in Rose-Ackerman \& Lindseth, supra note 2 at ch. 19.

26 Elena Kagan, "Presidential Administration" (2001) 114 Harv L Rev 2246.

27 For e.g., the choice of a discount rate and the proper way to monetize morbidity and mortality are both fraught with controversy even among those committed to the method of cost-benefit analysis. Edward R. Morrison, "Judicial Review of Discount Rates Used in Cost-Benefit Analysis," (1998) 65 U Chicago L Rev 1333; Cass R. Sunstein, "Incommensurability and Valuation in Law," (1994) 92 Mich L Rev 779 at 796.

28 Catherine Donnelly, "Participation and Expertise: Judicial Attitudes in Comparative Perspective" in Rose-Ackerman \& Lindseth, supra note 2 at ch. 21. 
move toward greater participation and stronger standards of transparency and reason-giving absent a massive public outcry. In the United States the $A P A$ arguably arose from congressional effort to constrain delegated policymaking under a separation-of-powers system. ${ }^{29}$ No such incentives exist in parliamentary systems. ${ }^{30}$

Paradoxically, however, many new regulatory agencies in Europe have introduced accountable procedures on their own initiative even though they are isolated from electoral politics. Case studies from the UK, France and Sweden show that the regulators supported greater public involvement because they needed outside support to survive and could imitate established models in the US and elsewhere. ${ }^{31}$ More participatory and transparent processes were seen as a way of increasing their own legitimacy. However, these moves did not always have that effect. Sometimes they simply increased the power of the regulated industry, thus increasing the risk of capture. Agencies reacted to this concern by taking steps to facilitate consumer input. ${ }^{32}$

For policies where a cost-benefit test seems appropriate, one response would be to combine cost-benefit analysis with transparency as a means of blocking agencies from adopting measures that benefit narrow interests. This requirement could have legal force if applied by the courts. As one of us has argued, ${ }^{33}$ a judicial presumption in favour of net benefit maximization increases the political costs for narrow groups, which would have to obtain explicit statutory language in order to have their interests recognized by courts and agencies. ${ }^{34}$ This proposal raises an important question that is central to the discussion of administrative litigation to which we now turn. What should be the judiciary's role in reviewing the policymaking activities of modern executive branch bodies and regulatory agencies?

\section{ADMINISTRATIVE LITIGATION}

There is a famous adage in French administrative law - juger l'administration, c'est encore administrer - "to judge the administration is still to administer." It recognizes the difficulty, if not impossibility, of separating the process of legal control from the underlying process of administration. External legal control, whether exercised by courts or court-like administrative tribunals like the French Conseil d'Etat, will always shape regulatory policy in a myriad of ways. Read most strongly, this French adage implies an ideal of a "self-regulating" administrative sphere that is detached from traditional values of justice and guided by its own sense of policy rationality and its own estimation of the public interest in the construction and regulation of the

29 Mathew D. McCubbins, Roger G. Noll \& Barry Weingast “Administrative Procedures as Instruments of Political Control" (1987) 3 JL Econ \& Org 243.

30 Terry M. Moe \& Michael Caldwell, "The Institutional Foundations of Democratic Government: A Comparison of Presidential and Parliamentary Systems" (1994) 150 Journal of Institutional and Theoretical Economics 171; Rose-Ackerman, Controlling Environmental Policy, supra note 23 at 7-17.

31 Dorit Rubinstein Reiss, "Administrative Agencies as Creators of Administrative Law Norms: Evidence from the UK, France, and Sweden" in Rose-Ackerman \& Lindseth, supra note 2 at ch. 22.

32 For e.g., the Office of Communications (Ofcom) in the UK, or the Autorité de Régulation de Télécommunications (ART) in France, opted for increased consumer input in various ways. See ibid.

33 Susan Rose-Ackerman, Rethinking the Progressive Agenda (New York: Free Press, 1992).

34 See also Cass Sunstein, Risk and Reason (Cambridge UK: Cambridge Univ. Press, 2002) at 191-228. 
market. $^{35}$ This adage, moreover, underlies the French dualité de juridiction, in which administrative judges, organically attached to the executive, are primarily competent to hear challenges to administrative action.

Historians and jurists, of course, have long understood that this strong reading does not comport well with reality. In his contribution to Comparative Administrative Law, Jean Massot, a member of the French Conseil d'Etat for over four decades, notes how the French system of administrative justice "progressively became both an extremely powerful judge and an institution at least as independent as its judicial counterparts." ${ }^{36}$ French administrative judges came to realize that, despite the potential impact of their rulings on administrative policy-making in the "general interest," their office still required independence, procedural fairness, even a willingness to revisit certain aspects of the underlying administrative act in the interest of justice in the particular case.

This tension between justice and administration - between the policy prerogatives of the state pursuing regulatory programs, on the one hand, and the demands of justice in individual disputes, on the other - is a key concern. Administrative litigation raises a set of questions familiar to any student of administrative law: Under what circumstances should we allow a private party to enlist the aid of an independent judge to rule on a dispute over administrative action? Who may seek that aid (standing)? When (timing)? On what issues (scope of review)? To what end (remedies)?

The approaches that particular polities have taken to these questions are deeply bound up with historical choices in response to functional, political, and cultural demands. The American "appellate review" model, for example, was inspired by the relationship between appellate and trial courts in civil litigation. ${ }^{37}$ The "office of the administrative judge" in France, by contrast, has focused on its guarantees of independence as well as its substantive ambition to reconcile the rights of individuals with the "general interest" represented by the state. ${ }^{38}$ The members of the French Conseil d'Etat exercise dual roles as both policy advisors to the government as well as judges of the governments' administrative acts.

The common law world provides yet another set of models. Thus, in Australia, administrative tribunals charged with merits review examine whether, all things considered, the challenged action is not merely legal but "correct or preferable." "This contrasts with the American system, where forms of agency review are functionally similar to "merits review," and the British, where there is a distinction between tribunal "appeal" (on law and fact) and judicial "review" (on law alone). Indeed, there is arguably not a crude civil law/common law divide (with continental Europe

\footnotetext{
Lindseth, supra note 5 at 119.

Jean Massot, "The Powers and Duties of the French Administrative Judge" in Rose-Ackerman \& Lindseth, supra note 2 at ch. 24.

37 Thomas W. Merrill, "The Origins of American-Style Judicial Review" in Rose-Ackerman \& Lindseth, supra note 2 at ch. 23.

38 Massot, supra note 36.

39 Peter Cane, "Judicial Review and Merits Review: Comparing Administrative Adjudication by Courts and Tribunals" in Rose-Ackerman \& Lindseth, supra note 2 at ch. 25. Ibid.
}

40 
largely representing the former, and the UK, US, and Canada the latter). ${ }^{41}$ Rather, US and Canadian judges favor deference, at least to some extent. UK judges, by contrast, seem to share the inclination of their more civilian colleagues in Europe, where the influence of French and German administrative justice is pervasive. Both UK and EU courts unhesitatingly substitute their judgment for that of administrators on questions of law. ${ }^{42}$

\section{THE BOUNDARIES OF THE STATE: PUBLIC AND PRIVATE}

Especially in countries with a civil law tradition, the distinction between public law and private law has been central to the development of administrative law. The common law tradition often obscured this boundary, but today all modern states recognize its existence. Given the ubiquity of a distinctive public law, the move over the last several decades to privatize and contract out government services presents a particular challenge. What legal principles should apply to private bodies that carry out formerly public functions or that take on new tasks under contract? Will the trend toward the use of nominally private firms lead to the integration of public and private law, even in states, such as France and Germany, where the public law/private law distinction has deep historical roots?

Privatization has many meanings, but three salient ones can be discerned. ${ }^{43}$ First, in its strongest form, privatization means that the state exits entirely from a sector or policy area leaving it to be governed only by the laws that regulate the actions of all private businesses and that frame private interactions. Second, a public utility may be converted into a private firm, with or without a "golden share" remaining in state hands, and placed under the supervision of an independent regulatory agency. Third, the state may decide that a nominally private firm must comply with some public law strictures in carrying out its business, even in the absence of oversight by a specific agency. This last category raises the most direct challenge to traditional public law/private law distinctions, especially in states with a civil law tradition. It also challenges libertarian presumptions about the inherent value of private enterprise compared to public bureaucracies as service providers.

A public law of privatization is needed and must start with a distinction between core government functions that ought not to be privatized and those where the private sector can be brought in under some conditions. ${ }^{44}$ Debate over this issue

41 Paul Craig, "Judicial Review of Questions of Law: A Comparative Perspective" in Rose-Ackerman \& Lindseth, supra note 2 at ch. 26.

42 In the UK, the leading cases are Anisminic Ltd v Foreign Compensation Commission [1969] 2 AC 147, and $\mathrm{R} v$ Hull University Visitor, exp Page [1993] AC 682. For more detail on the EU, see Paul Craig, EU Administrative Law (Oxford: Oxford University Press, 2006), ch. 13.

43 Daphne Barak-Erez, "Three Questions of Privatization" in Rose-Ackerman \& Lindseth, supra note 2 at ch. 29.

44 In our volume, Jean-Bernard Auby discusses the way contracts with government can extend public values to private service-delivery firms, but he stresses the risks inherent in programs of private provision for formerly state-supplied services. Jean-Bernard Auby, "Contracting Out and 'Public Values': A Theoretical and Comparative Approach" in Rose-Ackerman \& Lindseth, supra note 2 at ch. 30. These concerns have produced legal limits on contracting out in many countries, but they have also generated a range of responses - from careful contract drafting to self-regulatory mechanisms. In our volume as well, Laura Dickinson extends this analysis to the US military, often understood as beyond the scope of administrative law. Laura A. Dickinson, "Organizational Structure 
should consider institutional competence and risks to human rights. Different organizational forms may be more or less equipped to instill public law norms. Administrative law must articulate a set of public law principles that ought to apply to some degree to all entities that carry out public policies. ${ }^{45}$

These principles ought to distinguish among suppliers that provide standardized goods and services to public and private entities (for example, office supplies, asphalt roadways, computer systems); those that supply special purpose products but do not deliver services (for example, weapons producers, dam builders); and those that supply the public services themselves (for example, incarceration of convicted felons, primary education, garbage collection, review of applicants for government benefits). Drawing the lines between these categories will not be easy, but each raises distinct issues. The first is governed by market pressures and the law should assure that these pressures apply to government contracts and keep the process free of corruption and favoritism. The second requires greater attention both to the contracting process and to on-going oversight, but the aim is essentially timely and cost-effective contracting.

Finally, if public/private relationships extend to the third category, the law needs to do more than to assure simple contract compliance and to place limits on waste and corruption. Here, the use of private entities is arguably only justified if they take on some of the characteristics of public agencies and hence are governed by administrative and constitutional law principles that apply to government bodies. This includes making policy in a transparent and participatory way, rather than operating behind closed doors to allocate contracts or other benefits to particular sectors. Furthermore, once private firms are selected to implement a public program, they should be subject to duties that are similar to those facing public bodies. ${ }^{46}$

\section{THE BOUNDARIES OF THE STATE: TRANSNATIONAL ADMINISTRATION IN THE EU}

Some entities with regulatory authority operate beyond the state - perhaps internationally, like the GATT/WTO, or regionally and supra-nationally, like the EU. If their decisions affect rights and duties within states, how should we understand that power in legal terms? Should we understand it as a novel kind of "constitutional" authority, perhaps of an emerging proto-state? Or is it best understood as a denationalized extension of "administrative governance" on the national level? We do not pretend to answer these complex questions here, though one of us has argued extensively for an essentially "administrative, not constitutional"

and Institutional Culture in an Era of Privatization: The Case of Private Military Contractors in the United States" in Rose-Ackerman \& Lindseth, supra note 2 at ch. 31. She grounds her study in organizational theory by examining the relative impact of inside socialization and sanctions versus outside incentives in influencing behavior, a contrast with broader relevance beyond the specific case she examines.

46 An important variant on the public/private divide arises if a regulated sector, such as banking and finance, is in private hands, but becomes a serious public policy concern in a crisis. If some of the firms are "too big to fail," the state may intervene under emergency conditions. See generally Irma E. Sandoval, "Financial Crisis and Bailout: Legal Challenges and International Lessons from Mexico, Korea and the United States" in Rose-Ackerman \& Lindseth, supra note 2 at ch. 32 and Giulio Napolitano, "The Role of the State in (and after) the Financial Crisis: New Challenges for Administrative Law" in Rose-Ackerman \& Lindseth, supra note 2 at ch. 33. 
understanding of denationalized regulatory power in the EU. ${ }^{47}$ Scholars are increasingly looking to administrative law as a framework for understanding the exercise of rulemaking and adjudicative power beyond the state. ${ }^{48}$

Nowhere is this truer than in the legal literature on the European Union. Recently, a group of leading European administrative law scholars launched the Research Network on EU Administrative Law [ReNEUAL] that aims to draft a kind of "restatement" or "best practices" for administrative law in the EU. The ReNEUAL project will not only cover the administrative activities of EU bodies strictly speaking, but also those of national bodies implementing EU law. The project extends to the EU's participation in a variety of international regulatory and enforcement schemes that can also be understood in administrative law terms. ${ }^{49}$

The process of European integration has not only led to the development of a supranational EU administrative law, but it has also spurred a movement toward a deeply "Europeanized" administrative law on the national level as well. This process of Europeanization has had an impact well beyond those domains where Member States explicitly implement EU law. European integration is increasingly relying on a particular mode of governance - "adversarial legalism" - that was first observed in the United States by the American political scientist Robert Kagan. ${ }^{50}$ Adversarial legalism combines centrally formulated prescriptive rules and a diffuse and fragmented process of enforcement which depends crucially on judicial review to ensure compliance. Given its decentralized character, the European Court of Justice has understandably sought to impose some measure of uniformity on national administrative processes in order to ensure effective enforcement of EU rules and standards.

However, a concern arises from the growth of transnational networks - the challenge of safeguarding individual rights as networks spread. The network phenomenon is increasingly global in its scope, although transnational governance in the EU clearly presents the most developed example..$^{51}$ In the EU we see clearly the interplay between classic liberal rights (personal freedom, property rights, and other basic interests) and network decisionmaking that affects those rights. The dispersion of decisional power in networks means that one of the central concerns of traditional administrative law - the protection of the individual in the face of overreaching

47 Lindseth, supra note 16. See also Peter L. Lindseth, "Democratic Legitimacy and the Administrative Character of Supranationalism: The Example of the European Community" (1999) 99 Colum L R. 628; and Peter L. Lindseth, "Agents without Principals?: Delegation in an Age of Diffuse and Fragmented Governance" in Fabrizio Cafaggi, ed, Reframing Self-Regulation in European Private Law (Alphen aan den Rijn, Netherlands: Kluwer Law International, 2006).

48 See e.g. Benedict Kingsbury, Nico Krisch \& Richard B. Stewart, "The Emergence of Global Admimistrative Law” (2005) 68 Law \& Cont Probs 15; Herwig H.C. Hofmann \& Alexander H. Türk, eds, EU Administrative Governance, (Cheltenham UK: Edward Elgar, 2006); Herwig H.C. Hofmann \& Alexander H. Türk, eds. Legal Challenges in EU Administrative Law: Towards an Integrated Administration (Cheltenham UK: Edward Elgar, 2009).

49 George A. Bermann, "A Restatement of European Administrative Law: Problems and Prospects" in Rose-Ackerman \& Lindseth, supra note 2 at ch. 34.

50 Kagan, Robert, Adversarial Legalism: The American Way of Law (Cambridge, MA: Harvard University Press, 2001); R. Daniel Kelemen, "Adversarial Legalism and Administrative Law in the EU" in RoseAckerman \& Lindseth, supra note 2 at ch. 35.

51 Francesca Bignami, "Individual Rights and Transnational Networks" in Rose-Ackerman \& Lindseth, supra note 2 at ch. 37. 
public power - becomes vastly more challenging in the transnational administrative context. In confronting this challenge on a more global scale, the EU example, even with certain admitted complexities and drawbacks, may be helpful in developing models elsewhere.

\section{CONCLUSIONS}

Administrative law exists at the interface between the state and society - between civil servants and state institutions, on the one hand, and citizens, business firms, organized groups, and non-citizens, on the other. Civil service law and bureaucratic organization charts and rules provide the background, but administrative law's essential role is to frame the way individuals and organizations test and challenge the legitimacy of the modern state outside of the electoral process. There are two broad tasks - protecting individuals against an overreaching state and providing external checks that enhance the democratic accountability and competence of the administration.

Public law is the product of statutory, constitutional, and judicial choices over time; it blends constitutional and administrative concerns. The Germans speak of administrative law as "concretized" constitutional law, ${ }^{52}$ and Americans often call it "applied" constitutional law. "The English, with no written constitution, refer to "natural justice" and, more recently, to the European Convention on Human Rights [ECHR]. The French tradition of droit administratif contains within it a whole conceptual vocabulary - dualité de juridiction, acte administratif, service public - that has been deeply influential in many parts of the world. East Asia has a long tradition of centralized, hierarchical, and bureaucratic rule - a sort of "administrative law" avant la lettre. And yet, in forging its own modern variants, East Asia has also drawn on Western (and particularly German and US) models.

Administrative law is one of the "institutions" of modern government, in the sense that economists and political scientists often use that term. ${ }^{54}$ It is thus amenable to comparative political and historical study, not just purely legal analysis. The distinction between public and private is essential to administrative law, one that common law jurisdictions long sought to downplay by claiming that the same courts and legal principles should resolve both wholly private disputes and those involving the state. Nevertheless, even in the common law world, debates over the proper role and unique prerogatives of state actors are pervasive. Some scholars still assume that one can compartmentalize regulatory activities and actors into either a public or a private sphere. This may be analytically convenient, but it does not fit the increasingly

52 See e.g. Fritz Werner, "Verwaltungsrecht als konkretisiertes Verfassungsrecht” (1959) Deutsches Verwaltungsblatt 527.

53 See e.g. William D. Araiza, "In Praise of a Skeletal APA: Norton v. Southern Utab Wilderness Alliance, Judicial Remedies for Agency Inaction, and the Questionable Value of Amending the APA" (2004) 56 Admin L Rev 979 at 1002 (noting "the maxim that administrative law is applied constitutional law")

54 See e.g. Douglass C. North, Institutions, Institutional Change and Economic Performance (New York: Cambridge University Press, 1990) at 3-5; James G. March \& John P. Olsen. Rediscovering Institutions: The Organizational Basis of Politics (New York: Free Press, 1989); James G. March \& John P. Olsen. "The Institutional Dynamics of International Political Orders" (1998) 52 International Organization 943 at 948 . 
blurred boundary between state and society. Recent developments have also strained another familiar distinction, between justice and administration. In Europe, for example, courts regularly apply the principle of proportionality - if a policy interferes with a right, then it must be designed in the least restrictive way..$^{55}$ As a result, courts have begun to impose standards on government policymaking, at least when rights are at stake. Finally, international legal developments are increasingly influencing domestic regulatory and administrative bodies throughout the world. ${ }^{56}$

Our collective volume, Comparative Administrative Law, tries to take account of current developments in the field. It seeks to illuminate both the historical legacies and the present - day political and economic realities that continue to shape administrative law as we proceed into the twenty - first century. Our efforts are necessarily preliminary and are by no means exhaustive. Nevertheless, we aim to capture the complexity of the field and to distill key elements for comparative study. We look forward to further research and writing as the field grows and develops.

55 On the German origins of proportionality analysis and its diffusion throughout Europe and beyond, see Alec Stone Sweet and Jud Mathews, "Proportionality Balancing and Global Constitutionalism" (2008) 47 Colum J of Transnat'l L 73-165.

56 The project in Global Administrative Law centered at New York University, focuses on the administrative law of international organizations, such as the World Trade Organization.

Kingsbury et al, supra note 48. Nevertheless, it often draws on domestic models of the administrative process for inspiration. Our focus is complementary. We emphasize how the practices of multinational and regional bodies have both emerged out of and affected the administrative process in established states. 